\title{
ANALISI DATA HASIL PEMANTAUAN STATUS GIZI DARI FAKTOR DETERMINAN KEJADIAN STUNTING PADA BALITA
}

\author{
Hariani $^{1}$, I Made Rai Sudarsono ${ }^{1}$, Yeni sostinengari ${ }^{1}$ \\ ${ }^{1}$ Jurusan Gizi Poltekkes Kemenkes Kendari \\ ( Email : anigizi68@gmail.com )
}

\begin{abstract}
Background: Short child problems (stunting) are one of the nutritional problems faced in the world, especially in poor and developing countries. Based on the results of the nutritional status assessment in 2016, the national nutritional status of children under five years old TB / U or PB / U in the stunting category reached $27.5 \%$ in Southeast Sulawesi Province, the prevalence of stunting under five reached $29.5 \%$. Based on the results of the nutritional status assessment of the province of Southeast Sulawesi 2016, the prevalence of Konawe Regency reached 25.5\% above the national prevalence.
\end{abstract}

Research Objective: This study aims to determine the relationship between, parental height, exclusive breastfeeding, giving MP-ASI with stunting.

Research Methods: This type of research is an observational study with the design of a cross sectional study with a sample of 116 toddlers based on the analysis of nutritional status monitoring data in Konawe District, 2016. The independent variables in this study were exclusive breastfeeding, mother height, giving MP-ASI and stunting as the dependent variable. The type of data used in this study is secondary data from the results of monitoring nutritional status in Konawe Regency of Southeast Sulawesi Province in 2016.

Research Results: Stunting prevalence in Konawe Kepualauan 2016 reached 28,5\%. There is no relationship between Asi exclusively with stunting $(\mathrm{p}=0.941)$. There was no relationship between maternal height and stunting $(\mathrm{p}=1,000)$. There was no relationship between administration of MP-ASI with stunting $(\mathrm{p}=0.941)$.

Conclusion:. There is no relationships between giving MP-ASI, maternal height exclusive, breastfeeding with the incidence of stunting.

Keywords: stunting, Asi exclusive, maternal height, giving MP-ASI.

\section{PENDAHULUAN}

Memasuki era teknologi yang semakin Stunting atau pendek pada anak merupakan salah satu bentuk malnutrisi akibat keterbatasan keadaan sosial ekonomi secara keseluruhan di masa lampau. Stunting didefinisikan sebagai indeks tinggi badan menurut umur $(\mathrm{TB} / \mathrm{U})$ kurang dari minus dua standar deviasi $(<-2$ SD) atau tinggi badan balita itu lebih pendek dari yang seharusnya bisa dicapai pada umur tertentu (Kemenkes 2010).

Berdasarkan data Riset Kesehatan Dasar (Riskesdas) tahun 2007 di Indonesia mencatat bahwa prevalensi stunting sebesar 35,6\% meningkat dari tahun 2010 36,8\% dan tahun $201337,2 \%$. Persentase tersebut dengan pembagian untuk kategori sangat pendek $19,2 \%$ dan pendek $18,1 \%$ artinya diperkirakan lebih dari sepertiga $( \pm 8,9$ juta) anak usia dibawah 5 tahun di Indonesia mengalami pertumbuhan yang tidak sesuai ukuran standar internasional untuk tinggi badan berbanding usia. Selain itu, untuk anak Indonesia yang dalam keadaan kurus, diperkirakan ada sekitar 3,3 juta anak. Hasil Riskesdas tahun 2007 di Provinsi Sulawesi Tenggara mencatat prevalensi stunting sebesar $32 \%$ dan meningkat dari tahun 2010 yang angkanya sebesar 34\% dan pada tahun 2013 di sebesar $41 \%$. Berdasarkan hasil penilaian status gizi provinsi Sulawesi tenggara Prevalensi kejadian 
stunting di konawe kepulauan tahun 2016 yaitu sebesar $30,7 \%$.

Dengan demikian dapat disimpulkan bahwa di Kabupaten Konawe Kepulauan stunting masih menjadi masalah yang seriun kerena prevalensi stunting $>20 \%$. Berdasarkan data tersebut, maka peneliti tertarik untuk meneliti faktor determinan kejadian stunting di Kabupaten Konawe Kepulauan berdasarkan data hasil pemantauan status gizi (PSG) 2016.

\section{METODE}

\section{Jenis penelitian}

Jenis penelitian yang digunakan adalah penelitian observasional analitik dengan desaincrosssectionalstudy.

\section{Lokasi dan Waktu Penelitian}

Penelitian ini menggunakan data sekunder berasal dari Pemantauan Status Gizi (PSG) oleh dinas kesehatan provinsi Sulawesi Tenggara pada tahun 2016 dari data kabupaten Konawe Kepulauan.

\section{Populasi dan Sampel}

Populasi penelitian ini adalah seluruh

KK (kepala keluarga) yang memiliki balita yang terdapat dalam data Pemantauan Status Gizi di Kabupaten Konawe Kepulauan sebanyak $300 \mathrm{KK}$.

Sampel yang digunakan dalam penelitian ini adalah 91 sampel balita yang ada di rumah tangga terpilih dalam setiap klaster di Kabupaten Konawe Kepuluan.

\section{Pengumpulan Data}

Data ini merupakan data sekunder dari hasil kegiatan pemantauan status gizi oleh Dinas Kesehatan Provinsi Sulawesi Tenggara pada tahun 2017. Data yang akan dikumpulkan oleh peneliti adalah Data stunting, Data karakteristik keluarga, Data tinggi badan orang ibu, Data Riwayat Asi Ekslusif, Data MP-ASI dini.

\section{Pengolahan dan Analisis Data}

Analisis univariat yang dilakukan terhadap tiap variable dengan menggunakan tabel distribusi frekuensi sehingga menghasilkan distribusi dan persentasi setiap variabel. Analisis univariat digunakan untuk menggambarkan kejadian stunting pada balita tinggi badan orang tua, riwayat asi ekslusif, MP-ASI dini dan panjang badan lahir.

Analisis bivariat yang digunakan adalah uji chi square untuk melihat hubungan kejadian stunting pada balita dengan tinggi badan orang tua, riwayat asi ekslusif, MP-ASI dini dan panjang badan lahir dalam bentuk

tabulasi silang (crosstab) dengan menggunakan program komputer. Kriteria keputusan pengujian hipotesis terdapat hubungan antara variabel bebas dengan variabel terikat jika nilai $p<(0,05)$

\section{HASIL}

Kabupaten Konawe Kepulauan terbentuk berdasarkan Undang- Undang Republik Indonesia Nomor 13 Tahun 2013 tentang pembentukan daerah Tk. II di Sulawesi Tenggara yang merupakan daerah kabupaten otonom baru dari Kabupaten Konawe sebelumnya. Kabupaten Konawe Kepulauan terdiri dari 7 wilayah kecamatan dengan 95

desa/kelurahan. Kabupaten Konawe Kepulauan memiliki luas wilayah $295,89 \mathrm{Km}^{2}$, terdiri dari 7 kecamatan dan 95 kelurahan/desa. Wilayah kecamatan yang paling luas adaah Kecamatan Wawonii Tenggara yaitu 14.700 , Ha $(16,94 \%)$ dari luas Kabupaten Konawe Kepulauan sedangkan wilayah kecamatan dengan luas wilayah paling kecil adalah Kecamatan Wawonii Timur Laut yaitu sebesar $9.058 \mathrm{Ha}(10,44 \%)$

Tabel 1. Distribusi karakteristik keluarga balita di kabupaten konawe kepulauan

\begin{tabular}{ll|c|c}
\hline No & \multicolumn{1}{|c|}{ Kategori } & n & \% \\
\hline 1. & Pendidikan ayah & & \\
& a. tidak tamat SD & 5 & 5,5 \\
& b. tamat SD & 12 & 13,2 \\
& c. tamat SLTP & 30 & 33,0 \\
& d. tamat SLTA/MA & 35 & 38,5 \\
& e. tamat d1/d2/d3 & 3 & 3,3 \\
& f. tamat PT & 6 & 6,6 \\
\hline
\end{tabular}




\begin{tabular}{|c|c|c|c|}
\hline & Jumlah & 91 & 100 \\
\hline \multirow[t]{9}{*}{2.} & Pendidikan ibu & & \\
\hline & a. Tidak/belum pernah sekolah & 3 & 2,6 \\
\hline & b. tidak tamat SD & 2 & 2,2 \\
\hline & c. tamat SD & 14 & 15,4 \\
\hline & d. tamat SLTP & 25 & 27,5 \\
\hline & e. tamat SLTA/MA & 38 & 41,8 \\
\hline & f. tamat $\mathrm{d} 1 / \mathrm{d} 2 / \mathrm{d} 3$ & 4 & 4,4 \\
\hline & g. tamat PT & 5 & 5,5 \\
\hline & Jumlah & 91 & 100 \\
\hline \multirow[t]{8}{*}{3.} & Pekerjaan ayah & & \\
\hline & a. PNS/TNI/POLRI/BUMN/BUMD & 2 & 2,2 \\
\hline & b. pegawai swasta & 10 & 11,0 \\
\hline & c. Wiraswasta & 36 & 39,6 \\
\hline & d. Petani & 30 & 33,0 \\
\hline & e. Nelayan & 9 & 9,9 \\
\hline & f. Buruh & 4 & 4,4 \\
\hline & Jumlah & 91 & 100 \\
\hline \multirow[t]{7}{*}{4.} & Pekerjaan ibu & & \\
\hline & a. Ibu rumah tangga & 71 & 78,0 \\
\hline & b. PNS/TNI/POLRI/BUMN/BUMD & 1 & 1,1 \\
\hline & c. pegawai swasta & 1 & 1,1 \\
\hline & d. Wiraswasta & 8 & 98,8 \\
\hline & e. Petani & 9 & 9,9 \\
\hline & f. Buruh & 1 & 1,1 \\
\hline & Jumlah & 91 & 100 \\
\hline
\end{tabular}

Dari tabel 1 menunjukan bahwa pendidikan orang tua, khususnya pendidikan ayah balita dapat dilihat sebagian besar telah menempuh pendidikan dijenjang SLTA/MA $38,5 \%$ dan yang tamat perguruan tinggi sebesar 6,6\% dan untuk pendidikan ibu balita sebagian besar juga berpendidikan tamat SLTA/MA 41,8\% akan tetapi masih terdapat sebesar 3,3\% ibu balita yang Tidak/belum pernah sekolah. Sedangkan untuk pekerjaan ayah balita sebagian besar berprofesi sebagai petani sebesar 33,0\% meskipun daerah kepulauan akan tetapi masyarkatnya yang berprofesi sebagai nelayan hanya 9,9\% dan untuk pekerjaan ibu balita ternyata sebagian besar sebagai ibu rumah tangga yaitu 78,0\% dan sebanyak $9,9 \%$ bekerja sebagai petani.

Tabel 2. Distribusi Frekuensi Jenis Kelamin Balita Di Kabupaten Konawe Kepulu

\begin{tabular}{lcc}
\hline Jenis Kelamin Balita & n & \% \\
\hline Laki - Laki & 50 & 54,9 \\
Perempuan & 41 & 45,1 \\
\hline Total & $\mathbf{9 1}$ & $\mathbf{1 0 0}$ \\
\hline
\end{tabular}

Tabel 2 menunjukan sebagian besar sampel berdasarkan jenis kelamin pada balita dalam penelitian ini adalah laki-laki yaitu $54,9 \%$. 
Tabel 3. Distribusi Frekuensi Status Umur Balita Di Kabupaten Konawe Kepuluan

\begin{tabular}{lcc}
\hline \multicolumn{1}{c}{ Kelompok Umur Balita } & n & \% \\
\hline $6-12$ bulan & 28 & 30,7 \\
$12-24$ bulan & 40 & 43,9 \\
$24-59$ bulan & 23 & 25,2 \\
\hline Total & 91 & 100 \\
\hline
\end{tabular}

(Sumber : Data Sekunder PSG Tahun 2016)

Tabel 4. Distribusi Frekuensi Stunting Pada Balita Di Kabupaten Konawe Kepulauan

\begin{tabular}{llc}
\hline \multicolumn{1}{c}{ Status Gizi } & n & \% \\
\hline Normal & 65 & 71,4 \\
Stunting & 26 & 28,57 \\
\hline Total & 91 & 100 \\
\hline
\end{tabular}

(Sumber : Data Sekunder PSG Tahun 2016)

Prevalensi Stunting pada balita bahwa prevalensi stunting di Kabupaten ternyata sebesar $28,5 \%$. Hal ini menunjukan Konawe Kepulauan dikategorikan sedang.

Tabel 5. Distribusi Frekuensi Stunting Menurut kelompok umur Pada Balita Di Kabupaten Konawe Kepulauan

\begin{tabular}{|c|c|c|c|c|c|c|}
\hline Kelompok umur & Stu & nting & & & & tal \\
\hline & $\mathbf{n}$ & $\%$ & $\mathbf{n}$ & $\%$ & $\mathbf{n}$ & $\%$ \\
\hline $6-12$ bulan & 4 & 14,2 & 24 & 85,7 & 28 & 100 \\
\hline $12-24$ bulan & 13 & 46,4 & 27 & 67,5 & 40 & 100 \\
\hline $24-59$ bulan & 9 & 39,1 & 14 & 60,8 & 23 & 100 \\
\hline
\end{tabular}

Tabel 5 menunjukan prevalensi stunting menurut kelompok umur terlihat bahwa prevalensi stunting tertinggi berada pada kelompok umur 12-24 bulan yaitu $46,4 \%$ $(\mathrm{n}=13)$ sedangkan terrendah berada pada kelompok umur $6-12$ bulan yaitu $14 \%$. Semakin bertambah umur prevalensi stunting cenderung meningkat.

Tabel 6. Distribusi Frekuensi Tinggi Badan Ibu Di Kabupaten Konawe Kepuluan Tahun 2016

\begin{tabular}{lcc}
\hline \multicolumn{1}{c}{ Tinggi badan ibu } & n & \% \\
\hline Pendek $<150 \mathrm{Cm}$ & 35 & 38,4 \\
Normal $>150 \mathrm{Cm}$ & 56 & 61,5 \\
\hline Total & 91 & 100 \\
\hline
\end{tabular}


Tabel 7. Distribusi Frekuensi Pemberian ASI Ekslusif Balita Di Kabupaten Konawe Kepulauan

\begin{tabular}{lcc}
\hline \multicolumn{1}{c}{ Pemberian Asi Ekslusif } & n & \% \\
\hline ASI Ekslusif & 25 & 27,5 \\
ASI Non Eksklusif & 66 & 72,5 \\
\hline Total & $\mathbf{9 1}$ & $\mathbf{1 0 0}$ \\
\hline
\end{tabular}

Tabel 7 menunjukan Prevalensi balita yang non Asi Eksklusif lebih besar dibandingan dengan balita yang mendapatkan Asi Ekslusif (72,5\% > 27,5\%)

Tabel 8. Distribusi Frekuensi Pemberian MP-ASI pada Balita di Kabupaten Konawe Kepulauan Tahun 2016

\begin{tabular}{llc}
\hline \multicolumn{1}{r}{ Pemberian MP-ASI } & n & \% \\
\hline Ideal & 25 & 27,5 \\
MP-ASI Dini & 66 & 72,5 \\
\hline Total & $\mathbf{9 1}$ & $\mathbf{1 0 0}$ \\
\hline
\end{tabular}

Tabel 8 menunjukan prevalensi lebih besar dibandingkan dengan pemberian Pemberian MP-ASI terlalu Dini Pada balita MP-ASI ideal pada balita $(72,5 \%>27,5 \%)$.

Tabel 9.Hubungan Antara Tinggi Badan Ibu, Pemberian MP-ASI, Pemberian ASI Ekslusif Dengan Stunting Pada Balita Di Kabupaten Konawe Kepulaua

\begin{tabular}{|c|c|c|c|c|c|c|c|c|}
\hline \multirow[t]{3}{*}{ Variabel } & & & \multirow{2}{*}{\multicolumn{2}{|c|}{ normal }} & \multirow{2}{*}{\multicolumn{2}{|c|}{ Total }} & \multirow{3}{*}{$\mathbf{X}_{2}$} & \multirow{3}{*}{$\begin{array}{c}\text { P } \\
\text { value }\end{array}$} \\
\hline & \multicolumn{2}{|c|}{ Stunting } & & & & & & \\
\hline & $\mathrm{n}$ & $\%$ & $\mathrm{n}$ & $\%$ & $\mathrm{n}$ & $\%$ & & \\
\hline \multicolumn{9}{|l|}{ Tinggi Badan Ibu } \\
\hline Pendek $<150 \mathrm{~cm}$ & 10 & 28,6 & 24 & 71,6 & 35 & 100 & 0,000 & 1.000 \\
\hline Normal > $150 \mathrm{~cm}$ & 16 & 28,6 & 40 & 71,2 & 56 & 100 & & \\
\hline \multicolumn{9}{|l|}{$\begin{array}{l}\text { Pemberian MP-ASI } \\
\text { Ideal }\end{array}$} \\
\hline & 7 & 28,0 & 18 & 72,0 & 25 & 100 & 0.006 & 0.941 \\
\hline MP- ASI DINI & 19 & 28,8 & 47 & 71,2 & 66 & 100 & & \\
\hline \multicolumn{9}{|c|}{$\begin{array}{l}\text { Pemberian Asi Ekslusif } \\
\text { ASI Ekslusif }\end{array}$} \\
\hline & 7 & 28,0 & 18 & 72,0 & 25 & 100 & 0.006 & 0.941 \\
\hline ASI Non Ekslusif & 19 & 28,8 & 47 & 71,2 & 66 & 100 & & \\
\hline
\end{tabular}


Berdasarkan hasil analisis statistik chi square diketahui bahwa variabel Tinggi badan ibu, Asi Ekslusif dan Pemberian MP-ASI tidak berhubungan secara signifikan $(\mathrm{p}>0,05)$ dengan kejadian stunting. Berdasarkan data pada tabel 14 dapat dipahami bahwa prevalensi stunting pada balita terjadi sama besar antara tinggu badan ibu yang pendek dengan tinggi badan ibu yang normal $(28,6=28,6 \%)$. Sedangkan untuk Asi Ekslusif dan Pemberian MP-ASI prevalensi stunting pada balita terjadi lebih tinggi pada balita yang Asi non ekslusif dan pemberian MP-ASI terlalu dini $(28,8 \%>28,0 \%)$. Data kejadian stunting menurut Tinggi badan ibu, Asi Ekslusif dan Pemberian MP-ASI berbanding terbalik dengan harapan.

\section{PEMBAHASAN Stunting}

Stunting merupakan salah satu bentuk kurang gizi kronis yang ditandai dengan tinggi badan balita menurut umur diukur dengan standar deviasi menurut standar WHO 2005 <2 SD.

Pada penelitian ini, prevalensi stunting balita di Kabupaten Konawe Kepuluan tahun 2016 ditemukan prevalensi stunting usia 6-59 bulan sebesar $28,57 \%$. Berdasarkan standar WHO 1997 menunjukan bahwa apabila status gizi stunting berada pada kisaran 20-29\%

termasuk ketegori sedang. Sehingga, prevalensi stunting di Kabupaten Konawe Kepuluan termasuk dalam kategori sedang. Dengan demikian masalah stunting di Kabupaten Konawe pada tahun 2016 masih menjadi masalah kesehatan dimasyarakat.

Stunting pada perlu mendapatkan perhatian khusus termasuk pada anak balita usia 6-59 bulan. Proses pertumbuhan anak cenderung perlambatan sehingga peluang untuk terjadinya kejar tumbuh lebih rendah. Usia balita $6-59$ bulan merupakan usia anak mengalami perkembangan yang pesat dalam

kemampuan kognitif dan motorik. Diperkulukan kondisi fisik yang maksimal untuk mendukung perkembangan ini, dimana pada anak yang stunting perkembangan kemampuan motoric maupun kognitif dapat tertanggu.

\section{Hubungan Tinggi Badan Ibu dengan Stunting}

Hubungan Tinggi Badan Ibu dengan Stunting Tinggi badan ibu Berdasarkan analisis statistik chi square pada tabel 14 memperlihatkan proporsi balita stunting dari tinggi badan ibu yang normal dan tinggi badan ibu yang pendek sama dengan yaitu sebesar 28,6\% di bandingkan dengan balita dengan tinggi badan ibu pendek. Diperolah nilai $p=1,000(\geq 0,05)$ dengan demikian tidak berhubungan yang bermakna antara tinggi badan ibu dengan kejadian stunting pada balita. Penelitian ini sejalan dengan penelitian yang dilakukan oleh Atika Rahayu, dkk panel gizi makan desember (2014) yang menunjukan bahwa hasil uji statistik p-value adalah 0,488 menunjukan bahwa tidak terdapat hubungan yang bermakna antara tinggi badan ibu dengan kejadian stunting pada balita. Begitu pula dengan penelitian yang dilakukan oleh dewi Ngasyah,dkk Yogyakarta (2014) menunjukan hasil uji chi square pada $\alpha=0,05$ diperolah $\mathrm{p}=$ value sebesar 0,195 hal ini menunjukan bahwa tidak ada hubungan antara tinggi badan ibu dengan kejadian stunting pada balita.

Berbeda dengan Penelitian yang dilakukan oleh Nasikhah (2012) yang menunjukan bahwa anak yang dilahirkan dari ibu yang pendek beresiko menjadi stunting. Salah satu atau kedua orang tua yang pendek akibat kondisi patofisiologi (seperti defesiensi hormone pertumbuhan) memiliki gen dalam kromosom yang membawa sifat pendek sehingga memperbesar peluang ini mewarisi gen tersebut menjadi stunting. Akan tetapi, bila orang tua pendek akibat kekurangan zat gizi atau penyakit, kemungkinan anak dapat tumbuh dengan tinggi badan normal selama anak tersebut tidak terpapar faktor resiko lain.

\section{Hubungan Pemberian MP-ASI dengan Stunting}

Hubungan Pemberian MP-ASI dengan Stunting Pemberian MP-ASI Berdasarkan analisis statistik chi square memperlihatkan proporsi balita yang mendapat MP-ASI terlalu Dini memiliki status gizi stunting lebih banyak yaitu sebesar 28,8\% dibandingkan dengan balita yang pemberian Pemberian MP-ASI ideal (tabel 14). Diperolah nilai $\mathrm{p}=0,941$ $(\leq 0,05)$ dengan demikian tidak ada hubungan antara Pemberian MP-ASI dengan kejadian stunting pada balita. Penelelitian ini sejalan dengan Penelitian yang dilakukan oleh Friska meilyasari,dkk dipenogoro (2014) menunjukan tidak ada hubungan antara MP-ASI Dini dengan kejadian stunting hasil uji statistic $\mathrm{p}=$ value $(>0,05)$. Berbeda dengan penelitian yang dilakukan oleh Dwi puji Khasanah 
menemukan ada hubungan bermakna $(\mathrm{p}=0,02)$ antara waktu pertama kali pemberian MP-ASI dengan status gizi anak usis 6-23 bulan mempengaruhi kejadian stunting.

Pemberian MP-ASI terlalu dini meningkatkan resiko penyakit infeksi seperti diare kerna MP-ASI yang diberikan tidak sebersih dan mudah dicerna seperti ASI. Diare dihubungkan dengan gagal tumbuh karna terjadi malabsorbsi zat gizi selama diare. Jika zat gizi seperti zink dan tembaga serta air yang hilang selama diare tidak diganti maka akan timbul dehidrasi parah, malnutrisi, gagal tumbuh bahkan kematian. Selain pemberian MP-ASI yang terlalu dini terlambatnya memberikan MP-ASI juga menyebabkan pertumbuhan dan perkembangan balita menjadi terhambat karna kebutuhan balita tidak tercukupi. Keluarga yang memberikan pola asuh baik terutama terhadap kebutuhan zat gizi, maka akan mempengaruhi status gizi anak. Pemberian MP-ASI yang tepat pada anak usia 12-24 bulan akan menurunkan risiko malnutrisi, karena pada usia tersebut kebutuhan zat gizi anak tidak dapat tercukupi hanya dari ASI saja.

Hubungan ASI Ekslusif dengan Stunting Pemberian Asi Ekslusif pada balita

Berdasarkan analisis statistik chi square pada tabel 14 memperlihatkan proporsi yang tidak mendapatkan Asi Ekslusif memiliki status gizi stunting lebih banyak yaitu sebesar 28,8\% dibandingkan dengan balita yang diberi Asi Ekslusif. Diperolah nilai $\mathrm{p}=0,941 \quad(>0,05)$ dengan demikian tidak ada hubungan antara Pemberian Asi Ekslusif dengan kejadian stunting. Penelitian ini sejalan dengan penelitian yang dilakukan oleh syifa

Vaozia,dkk diponegoro (2016), hasil penelitiannya menunjukan bahwa riwayat asi ekslusif bukan merupakan faktor resiko kejadian stunting pada anak usia 1-3 tahun dengan uji statistik $\mathrm{p}=$ value 0,058 .

Berbeda dengan penelitian yang dilakukan oleh Hidayah tahun 2013 yang menemukanan bahwa ada hubungan bermakna antara ASI eksklusif dengan kejadian stunting pada anak balita. Demikian juga penelitian sebelumnya oleh Arifin (2012) yang berjudul analisis sebaran faktor resiko stunting pada balita di kabupaten purwakarta 2012, hasil penelitian diperoleh hasil multivariate faktor yang paling dominan adalah pemberian ASI yang mempengaruhi stunting 3,1\% (OR 3,1
95\% 1.434-6.835). Terdapat hubungan pemberian Asi Ekslusif dengan kejadian stunting pada balita 2-3 tahun, dimana diperolah nilai $p$-value $=0,000$ dengan taraf signifikan $5 \%$ p-value $(0,000 \leq 0,05)$. (Indrawati,2016)

Pemberian ASI Ekslusif tidak memiliki hubungan dengan kejadian stunting pada anak usia 6-59 bulan. Hal ini terjadi karena sebagian besar Ibu balita tidak memberikan. Stunting dipengaruhi oleh riwayat pemberian ASI eksklusif dan penyakit infeksi, seperti diare dan Infeksi Saluran Pernafasan Akut (ISPA). Kebutuhan zat gizi pada usia 0-6 bulan dapat dipenuhi dari ASI. Anak yang tidak mendapatkan ASI eksklusif berisiko lebih tinggi untuk kekurangan zat

gizi yang diperlukan untuk proses pertumbuhan. Begitu juga anak yang mengalami infeksi rentan terjadi status gizi kurang. Anak yang mengalami infeksi jika dibiarkan maka berisiko terjadi stunting. ASI eksklusif dapat menurunkan risiko kejadian stunting, karena kandungan kalsium pada ASI mempunyai bioavailabilitas yang tinggi sehingga dapat diserap dengan optimal terutama dalam fungsi pembentukan tulang anak.

\section{KESIMPULAN DAN SARAN}

Dari hasil penelitian dapat disimpulkan yaitu Tidak terdapat hubungan yang signifikan antara Tinggi Badan Ibu dengan kejadian stunting pada balita usia 6-59 bulan di Kabupaten Konawe Kepulauan. Tidak ada hubungan antara Pemberian ASI Ekslusif dengan kejadian stunting pada balita usia 6-59 bulan di Kabupaten Konawe Kepulauan. Tidak ada hubungan antara pemberian MP-ASI dengan kejadian stunting pada balita usia 6-59 bulan di Kabupaten Konawe Kepulauan.

Diharapkan peneliti selanjutnya dapat memperluas penelitian dengan menambah variabel lain yang memiliki pengaruh dan menggunakan data primer dalam melakukan penelitian stunting pada balita sehingga diperoleh suatu perbandingan hasil penelitian terhadap variabel independen dan dependen yang diteliti. Selain itu, diharapkan juga untuk penelitian selanjutnya dapat melanjutkan dengan metode penelitian dan analisis yang lebih tingkat ke validitasnya (mengurangi bias) dalam penelitian, seperti metode kohort, dan lain-lain. 


\section{DAFTAR PUSTAKA}

Arsyad,A. (2011) Media pembelajaran. Afia, Amin Nur. Dkk. 2014. Faktor Sosiodemografi dan Tinggi Badan Orang Tua Serta Hubungannya dengan Kejadian Stunting pada Balita Usia 6 23 Bulan. Jurnal Gizi Dan Dietetika Indonesia. Edisi September $2014 \mathrm{Vol}$ 2, No. $3: 170-177$

Abdulah, A.Z. 2012. Survey Pertumbuhan Anak Melalui Pendekatan Learning Organization. Pustaka Timur. Yogyakarta.

Anisa, P. 2012. Faktor - Faktor yang Berhubungan dengan Kejadian Stunting pada Balita Usia 25 - 60 Bulan Di Kelurahan Kalibaru Depok. Universitas Indonesia. Skripsi

Arifin. 2012. Faktor - Faktor Penyebab Kegagalan Pemberian ASI Ekslusif. Medical Journal Of Lampung University. Volume 2 No 4 Februari 2013.

Atika rahayu, laily khairiyati. 2014. Resiko pendidikan ibu terhadap kejadian stunting pada anak 6-23 bulan (meternal education as risk faktor stunting of child 6-23 months old).fakultas kesehatan masyarakat, universitas lampung mangkurat. Volume 37

Bunga astria paramashanti,dkk. 2015. Pemberian asi ekslusif tidak berhubungan dengan stunting pada anak usia 6-23 bulan di Indonesia.stikes alma ata Yogyakarta. Jurna gizi dan dietetik Indonesia.

Ernawati, F. Dkk. 2013. Pengaruh Asupan Protein Ibu Hamil dan Panjang Badan Bayi Lahir terhadap Kejadian Stunting pada Anak Usia 12 Bulan Di Kabupaten Bogor. Penelitian Gizi Dan Makanan. Edisi juni 2013 vol. 36 (1) : $1-11$.

Friska meilyasari,dkk. 2014. Faktor resiko kejadian stunting pada balita usia 12 bulan di desa purwokerto kecamatan patebon, kabupaten Kendal. fakultas kedokteran universitas diponegoro Volume 3, nomor 2

Indrawati Sri, 2016. Hubungan Pemberian Asi Ekslusif Dengan Kejadian Stunting Pada Anak Usia 2-3 Tahun Di Desa
Karangrejek Wonosari Gunungkidul. Universitas Aisyiyah Yogyakarta.

Kementerian kesehatan RI. 2013. Riset kesehatan dasar. Jakarta

Kusuma, E.K. 2013. Faktor Resiko Kejadian Stunting Pada Anak Usia 2-3 Tahun. Universitas Di Ponegoro. Artikel Penelitian.

Marquis, G.S.Habicth, J.P.

Lanata,

C.F.Black,E.R.Rasmussen,K.M.1997. Association Of Breastfeeding And Stunting In Peruvian Toddlers : An Example Of Reverse Causality. International Journal Of Epidemiology. Vol. 26, No. 2.

Meilyasari, F, Isnawati, M. 2014. Faktor Resiko Kejadian Stunting Pada Balita Usia 12 - 36 Bulan Di Desa Purwokerto Kecamatan Patebon, Kabupaten Kendal. Journal Of Nutrition College. Vol. 3, No. 2.

Mendez, M. A. \& Adair, L.S. 1999. Severty And Timing In The Frist Two Year Of Life Affect Performance On Congnitive Tests I Late Childhood, The Journal Of Nutrition, 129 : 15551562.

Maharsiwi, Anggar. 2014. Hubungan Antara Pemberian MP-ASI Dini dengan Kejadian Stunting Gizi Lebih pada Bayi Usia 6 - 24 Bulan Di Wilayah Kerja Puskesmas Kartasura, Sukoharjo. Universitas Muhamadiah Surakarta. Skripsi

Monica, Dalimunthe Shella. 2015. Gambaran Faktor - Faktor Stunting pada Balita Usia 24 - 59 Bulan di Provinsi Nusa Tenggara Barat Tahun (2010) ( Analisis Data Sekunder Riskesdas 2010). Universitas Islam Negri Syarif Hidayahtullah. Skripsi

Nadiyah, R. 2012. Faktor resiko kejadian stunting pada balita usia 24-59 bulan di kecamatan semarang timur. universitas diponegoro. Artikel penelitian

Nasikhah, R. 2012. Faktor Resiko Kejadian Stunting Pada Balita Usia 24 - 36 Bulan Di Kecamatan Semarang Timur. Universitas Diponegoro . Artikel Penelitian.

Rahayu, B. Dkk. 2011. Pengaruh BBLR dan Pemberian Asi Ekslusif Terhadap Perubahan Status Gizi Stunting Pada 


\author{
Balita Di Kota Dan \\ Kabupaten \\ Tangerang Provinsi Banten. \\ Universitas Muhamadiyah Prof. Dr. \\ HAMKA.
}

Rr dewi ngaisyah dkk. 2014. Hubungan tinggi badan orang tua dengan kejadian stunting. Universitas respatih Yogyakarta. Jurnal ilmu kebinanan, jilid 3 nomor 1

Siahaan, Novita. Dkk. 2013. Faktor - Faktor yang Berhubungan dengan Kejadian Stunting Pada Balita di Wilayah Kerja Puskesmas Tanjung Tiram Kecamatan Tanjung Tiram Kabupaten Batu Bara. Fakultas Kesehatan Masyarakat USU.

Prasetyono, 2009. Buku Pintar ASI Ekslusif Pengenalan, Praktik Dan Kemanfaatan- Kemanfaatannya. Yogyakrta : Diva press.

Putra Onetusfifsi. 2016. Pengaruh BBLR Terhadap Kejadian Stunting Pada
Anak Usia 12 - 60 Bulan Diwilayah Kerja Puskesmas Pauh. Fakultas Kesehatan Masyarakat Universitas Andalas. Padang.

Nasikhah Rounhotun. 2012. Faktor Resiko Kejadian Stunting Pada Balita Usia 24 - 36 Bulan Di Kecamatan Semarang Timur. Universitas Diponerogo Semarang. Artikel penelitian.

Syifa voazia, dkk. 2016. Faktor resiko kejadian stunting pada anak usia 1-3 tahun (studi di desa menduren kecamatan brati kabupaten grobogan.fakultas kedokteran universitas diponegoro. Volume 5, nomor 4.

Trihono, Atmarita, Tjandraini, DH, irmawati, A, Utami.N.H, tejayanti. T. Nurlinawati,L. 2015. Pendek (stunting) di Indonesia masalah dan solusinya. Balitbengkes. Jakarta. 